\title{
Internalization of gonadotropin-releasing hormone receptors (GnRHRs): does arrestin binding to the C-terminal tail target GnRHRs for dynamin-dependent internalization?
}

\author{
James N Hislop*, Christopher J Caunt ${ }^{\star 1}$, Kathleen R Sedgley ${ }^{1}$, Eammon Kelly², \\ Stuart Mundell ${ }^{2}$, Lisa D Green ${ }^{1}$ and Craig A McArdle ${ }^{1}$ \\ University of California, San Fransisco, California, USA \\ ${ }^{1}$ Laboratories for Integrative Neuroscience and Endocrinology, Dorothy Hodgkin Building and ${ }^{2}$ Department of Pharmacology, University of Bristol, Whitson Street, Bristol \\ BS1 3NY, UK \\ (Requests for offprints should be addressed to C A McArdle; Email: craig.mcardle@ bris.ac.uk) \\ *(J N Hislop and C J Caunt contributed equally to this work)
}

\begin{abstract}
Activation of seven-transmembrane receptors is typically followed by desensitization and arrestin-dependent internalization via vesicles that are pinched off by a dynamin collar. Arrestins also scaffold Src, which mediates dynamin-dependent internalization of $\beta 2$-adrenergic receptors. Type I mammalian gonadotropin-releasing hormone receptors (GnRHRs) do not rapidly desensitize or internalize (characteristics attributed to their unique lack of C-terminal tails) whereas non-mammalian GnRHRs (that have C-terminal tails) are rapidly internalized and desensitized. Moreover, internalization of Xenopus (X) GnRHRs is dynamin-dependent whereas that of human ( $h$ ) GnRHRs is not, raising the possibility that binding of arrestin to the C-terminal tails of GnRHRs targets them to the dynamin-dependent internalization pathway. To test this we have compared wild-type GnRHRs with chimeric receptors (XGnRHR C-terminal tail added to the hGnRHR alone (h.XtGnRHR) or with exchange of the third intracellular loops (h.XI.XtGnRHR)). We show that adding the XGnRHR C-terminal tail facilitates arrestin- and dynamin-dependent internalization as well as arrestin/green fluorescent protein translocation, but Src (or mitogen-activated protein kinase/extracellular-signal-regulated kinase kinase) inhibition does not slow internalization, and h.XtGnRHR internalization is slower than that of the hGnRHR. Moreover, arrestin expression increased XGnRHR internalization even when dynamin was inhibited and h.XI.XtGnRHR underwent rapid arrestin-dependent internalization without signaling to $G_{q / 11}$. Thus, although the $\mathrm{C}$-terminal tail can direct GnRHRs for arrestin- and dynamin-dependent internalization, this effect is not dependent on Src activation and arrestin can also facilitate dynamin-independent internalization.
\end{abstract}

Journal of Molecular Endocrinology (2005) 35, 177-189

\section{Introduction}

Gonadotropin-releasing hormone (pGlu-His-Trp-SerTyr-Gly-Leu-Arg-Pro-Gly-NH $\mathrm{NH}_{2}$; GnRH-I) acts via $\mathrm{G}_{\mathrm{q} /}$ 11-coupled seven-transmembrane region receptors (7TM receptors) to stimulate phospholipase $\mathrm{C}$ (PLG). The consequent mobilization of $\mathrm{Ca}^{2+}$ and activation of protein kinase $\mathrm{C}(\mathrm{PKC})$ isozymes mediates effects of $\mathrm{GnRH}$ on gonadotropin synthesis and secretion (Conn \& Crowley 1994, Sealfon et al. 1997, Stojilkovic \& Catt 2000). Most vertebrates express the highly conserved GnRH-II ([His $\left.\left.{ }^{5}, \operatorname{Trp}^{7}, \mathrm{Tyr}^{8}\right] \mathrm{GnRH}\right)$ along with one or more related peptides. These different forms of $\mathrm{GnRH}$ have apparently evolved in parallel with distinct gonadotropin-releasing hormone receptors (GnRHRs; Sealfon et al. 1997, Millar et al. 2001) that can be classified phylogenetically into three groups. The best-characterized are the mammalian type I GnRHRs that mediate central control of reproduction. These are selective for GnRH-I and, unlike all other G-protein-coupled receptors (GPCRs), lack G-terminal tails. All other characterized GnRHRs (non-mammalian type I GnRHRs, mammalian and non-mammalian type II GnRHRs and type III GnRHRs) are selective for GnRH-II (as compared with GnRH-I) and have G-terminal tails of varying length (Millar et al. 2001, Neill et al. 2001, Millar 2002, Morgan et al. 2003).

Sustained stimulation typically causes desensitization and internalization of 7TM receptors and the established model for rapid homologous receptor regulation involves their phosphorylation by G-protein receptor kinases (GRKs). This most often occurs in the receptor's C-terminal tail or third intracellular loop and facilitates binding to arrestins 2 or 3 ( $\beta$-arrestins 1 and 2), reducing G-protein coupling and targeting the desensitized receptor for internalization via clathrin-coated vesicles. These clathrin-coated vesicles are then pinched off by a dynamin collar, an effect that can be blocked by 
GTPase-inactive (dominant negative) mutants such as K44A dynamin 1 (Vieira et al. 1996). The internalized receptors are then recycled back to the surface membrane or degraded (Miller \& Lefkowitz 2001, Luttrell \& Lefkowitz 2002, Pierce et al. 2002). Since internalization of non-mammalian GnRHRs can be slowed by removal of C-terminal-tail phosphorylation sites, and accelerated by arrestins, this model appears applicable to these receptors (Heding et al. 1998, Vrecl et al. 1998, Blomenrohr et al. 1999, McArdle et al. 2002). In contrast, it has not been possible to demonstrate agonist-induced phosphorylation or arrestin binding with mammalian type I GnRHRs. This apparently reflects the unique absence of $\mathrm{C}$-terminal tails from these receptors and explains their resistance to desensitization and slow rate of internalization (Davidson et al. 1994, McArdle et al. 1995, 1996, 2002, Heding et al. 1998, 2000, Willars et al. 1998, 1999, 2001, Vrecl et al. 1998, Blomenrohr et al. 1999, Hislop et al. 2000, 2001). As a further distinction, we have expressed human and Xenopus GnRHRs in HeLa cells expressing K44A dynamin 1 and found that the internalization of the mammalian GnRHR is insensitive to dynamin, whereas that of the non-mammalian receptor is dynamindependent (Hislop et al. 2001).

In addition to the established role in GPCR desensitization and endocytosis, arrestins also function as scaffold proteins, binding multiple signaling molecules and allowing the classically 'desensitized' receptor to signal from endosomes via a non-G-protein signaling cascade. Thus, for example, activation of ATla angiotensin receptors causes formation of a complex containing the receptor, arrestin 2, Rafl and extracellular-signal-regulated kinase (ERK) that facilitates ERK activation by the receptor (Miller \& Lefkowitz 2001, Luttrell \& Lefkowitz 2002, Pierce et al. 2002). Similarly, $\beta 2$-adrenergic receptor activation also causes Src to bind arrestin 2, facilitating tyrosine phosphorylation of dynamin. This effect is inhibited by mutations of arrestin that prevent its binding to $\mathrm{Src}$ and since such mutations also block dynamin-dependent $\beta 2$-adrenergic receptor internalization, the scaffolding of Src to $\beta 2$-adrenergic receptor-bound arrestin is thought to mediate internalization (Ahn et al. 1999, Miller \& Lefkowitz 2001, Luttrell \& Lefkowitz 2002, Pierce et al. 2002, Luttrell 2003). Extending this paradigm to GnRHRs we hypothesized that binding of arrestins to the C-terminal tails of non-mammalian (but not mammalian type I) GnRHRs would mediate Srcdependent activation of dynamin-dependent internalization. Here we have compared wild-type human (h) GnRHRs and Xenopus (X) GnRHRs with chimeric receptors in which the G-terminal tail of the XGnRHR is added to the hGnRHR, either alone (h.XtGnRHR chimera) or in addition to replacement of the hGnRHR third intracellular loop with that from the
XGnRHR (h.Xl.XtGnRHR). We find that addition of the $\mathrm{C}$-terminal tail facilitates arrestin- and dynamindependent internalization as well as agonist-induced arrestin translocation. However, inhibition of Src (or mitogen-activated protein kinase (MAPK)/ERK kinase $(\mathrm{MEK})$ ) failed to slow internalization of the wild-type or h.XtGnRHRs and internalization of the h.XtGnRHR was slower than that of the hGnRHR in spite of the fact that the hGnRHR does not bind arrestin. Moreover, transfection with arrestin increased XGnRHR internalization even when dynamin-dependent internalization was inhibited and h.Xl.XtGnRHR underwent rapid arrestin-dependent internalization in spite of the fact that it does not signal to $G_{\mathrm{q} / 11}$. Thus, although the C-terminal tail can direct GnRHRs to an arrestin- and dynamin-dependent internalization pathway, this effect is not dependent on Src or ERK activation, and arrestin can also facilitate dynamin-independent GnRHR internalization.

\section{Materials and methods}

\section{Materials and cell culture}

GnRH-I and GnRH-II (originally termed chicken GnRH) were purchased from Sigma (Poole, Dorset, UK). Buserelin and $\left[{ }^{125} \Gamma\right]$ Buserelin ([T-BuSer ${ }^{6}$, Pro $^{9}$ NHET]GnRH， $2000 \mathrm{Ci} / \mathrm{mmol}$ ) were provided by Professor Sandow (Aventis Pharma GmbH, Frankfurt, Germany). [ $\left.{ }^{125} \mathrm{I}\right] \mathrm{GnRH}-\mathrm{II}$ (approximately $3400 \mathrm{Ci} / \mathrm{mmol}$ as determined by self-displacement) was prepared using chloramine-T and purified by G-25 Sephadex column chromatography. Culture media, sera and plasticware were from Gibco/BRL (Paisley, UK) or Falcon (Becton Dickinson, Oxford, UK). FuGENE 6 was from Roche (Lewes, E. Sussex, UK) and Superfect was from Qiagen (Crawley, Surrey, UK). cDNAs encoding wild-type GnRHRs (human and Xenopus), arrestin 2 and 3/green fluorescent protein (GFP), $\Delta$-arrestin(319-418) and K44A dynamin 1 were kindly provided by Professor R Millar (Medical Research Council Human Reproductive Sciences Unit, Edinburgh, UK), Professor J L Benovic (Thomas Jefferson University, Philadelphia, PA, USA) and Professor S Schmidt (Scripps Institute, La Jolla, CA, USA). The adenovirus (Ad) expressing the K44A dynamin 1 dominant negative mutant was provided kindly by Professor J Pessin (SUNY, New York, NY, USA).

\section{Engineering of receptors}

Chimeric receptors were generated by splicing overlapextension PCR products as shown in Fig. 1 and described in Horton et al. (1989), Caunt et al. (2004) and Finch et al. (2004). These were based on the hGnRHR but had either the G-terminal tail of the XGnRHR 


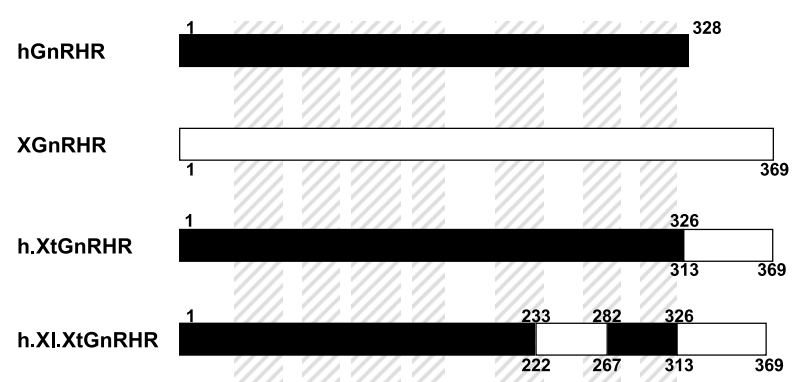

Figure $1 \mathrm{GnRHR}$ chimeras. Human and Xenopus GnRHR sequences are indicated in black and white, respectively, with amino-acid residues at splice sites shown above (hGnRHR) and below (XGnRHR) the bars. The diagonal lined regions regions show the approximate locations of the transmembrane regions.

added to the C-terminus (h.XtGnRHR) or third intracellular loop replaced with that from the XGnRHR (h.XlGnRHR) or had both alterations (h.Xl.XtGnRHR). For the h.XtGnRHR chimera, primers (a), 5'-AAG CTG CAG TTT TTC ACA ATG GTG -3', and (b), 5'-ATG AGG GAG TAA AAT ATC CAT AGA TAA GTG GAT $C-3^{\prime}$, were used to amplify DNA from wild-type hGnRHR cDNA template, while primers (c), 5'-CTA TGG ATA TTT TAC TCG CTC ATT CAA AGA GG-3', and (d), 5'-CCG GCT CGA GTC AGA AGA CTG ATT GCA TGG T-3', were used to amplify DNA from a wild-type XGnRHR cDNA template in a separate reaction. Regions in italic indicate sequences complementary to hGnRHR DNA, where normal text indicates complementary sequences to XGnRHR. Underlined regions denote PstI and XhoI restriction sites. The products of these reactions were then used in a splicing PCR reaction using primers (a) and (d), and the resultant product sub-cloned back into a corresponding PstI to XhoI digest of wild-type hGnRHR in pCR3 vector (Invitrogen, Paisley, UK).

The h.XlGnRHR chimera was generated using the same technique. First, a half human/half Xenopus cDNA was constructed by performing a PCR of the hGnRHR using primers (e), 5'-TGG CCT GGA TCC TCA GTA GTA $G T G$-3', and (f), 5'-GTG TTT CAT CTG CCG TGT $C A G G G T$ GAA-3', whereas a region of the XGnRHR was amplified using primers (g), 5'-ACC CTG ACA CGG CAG ATG AAA CAC AAG AAT GAG C-3', and (d). Regions in italic indicate complementary sequences to hGnRHR DNA, whereas normal text indicates complementary sequences to XGnRHR. The underlined region denotes a BamHI restriction site. The products of these reactions were then used in a splicing PCR reaction using primers (e) and (d), and subcloned back into a corresponding digest of the hGnRHR in pCMVZeo (Invitrogen). Primers (h), 5'-GTG TGG TGG ACG CCC TAC TAT GTC CTA GGA ATT TG-3', and (i), 5'-ACT GTC GAC CTC GAG TCA CAG AGA AAA
ATA TCC-3', were used to amplify DNA from wild-type hGnRHR, while primers (e) and (j), 5'-TAG GAC ATA GTA GGG GGT CCA GCA GAC CAT AAA GG-3', were used to amplify DNA from half human/half Xenopus GnRHR template in a separate reaction. Regions in italic indicate complementary sequences to hGnRHR DNA, whereas normal text indicates complementary sequences to XGnRHR. The underlined region denotes a SphI restriction site. The products of these reactions were then used in a splicing PCR reaction using primers (e) and (i), and subcloned back into a corresponding digest of the hGnRHR in pCMVZeo. The double h.Xl.XtGnRHR was then constructed in the way as the single h.XtGnRHR chimera, using primers (a), (b), (c) and (d) to add the C-terminal tail to the h.XlGnRHR. The h.XlGnRHR and h.Xl.XtGnRHR chimeric cDNAs were then subcloned into an EcoRI-XhoI digest of the pCR3 vector. Arrestin (2 or 3)/GFP, hGnRHR, XGnRHR and h.XtGnRHR were subcloned into the Ad transfer vector $\mathrm{pXCXCMV}$. The recombinant viruses were then generated by homologous recombination with pJM17 (Microbix Systems, Toronto, Canada) in HEK-293 cells, grown to high titre and then purified by $\mathrm{CsCl}$ density-gradient centrifugation as described by Hislop et al. (2000, 2001). The Ad expressing the K44A dynamin 1 dominant negative mutant was grown to high titre as above.

\section{Cell culture and transfection}

HeLa cells stably expressing K44A dynamin 1 were cultured in serum-supplemented Dulbecco's modified Eagles medium (DMEM) with G418 (300 $\mu \mathrm{g} / \mathrm{ml})$, puromycin $(100 \mathrm{ng} / \mathrm{ml})$. Tetracycline $(1 \mu \mathrm{g} / \mathrm{ml})$ was routinely included in the culture medium to prevent transgene expression but in some cases this was omitted in order to permit K44A dynamin 1 expression and thereby block dynamin-dependent internalization (Vieira et al. 1996). For experiments, cells were harvested by trypsinization, plated in DMEM supplemented with $2 \%$ serum, and incubated for 2 days in flasks or culture plates as described in the figure legends. In some experiments cells were transfected by infection with recombinant Ad expressing GnRHRs or K44A dynamin 1, as described in Hislop et al. (2000, 2001). The Ad-containing medium was removed after approximately 4-6 h and replaced with fresh medium, with or without tetracycline. The cells were then maintained for 1-2 days in culture before use in the binding assays. Alternatively, they were transiently transfected with pCR3 vectors encoding GnRHRs with or without arrestin 2/GFP, arrestin 3/GFP, $\Delta$-arrestin(319-418) or K44A dynamin 1, using Superfect and following the manufacturer's instructions. These cells were also maintained in culture for a further 1-2 days prior to use 
in binding assays or $\left[{ }^{3} \mathrm{H}\right]$ inositol phosphate $\left(\left[{ }^{3} \mathrm{H}\right] \mathrm{IP}_{\mathrm{x}}\right)$ accumulation assays. HeLa cells not expressing the $\mathrm{K} 44 \mathrm{~A}$ transgene were maintained and seeded as above but with the omission of antibiotics. They were transfected with vectors encoding GnRHRs using Superfect and maintained in culture for a further $24 \mathrm{~h}$ before being used for confocal microscopy.

\section{Radioligand binding and internalization assays}

Radioligand binding to cell-surface GnRHRs was quantified using whole-cell binding assays, with cells in suspension or grown in culture plates. For suspension binding approximately 50000 cells were incubated for $30 \mathrm{~min}$ at $21{ }^{\circ} \mathrm{C}$ in $100 \mu \mathrm{l}$ physiological salt solution (PSS; $127 \mathrm{mM} \mathrm{NaCl}, 1 \cdot 8 \mathrm{mM} \mathrm{CaCl}_{2}, 5 \mathrm{mM} \mathrm{KCl}, 2 \mathrm{mM}$ $\mathrm{MgCl}_{2}, 0.5 \mathrm{mM} \mathrm{NaH} \mathrm{PO}_{4}, 5 \mathrm{mM} \mathrm{NaHCO}, 10 \mathrm{mM}$ glucose, $0 \cdot 1 \% \mathrm{BSA}$ and $10 \mathrm{mM}$ Hepes, $\mathrm{pH} 7 \cdot 4$ ) containing $1 \mathrm{mg} / \mathrm{ml}$ bacitracin with approximately $10^{-10} \mathrm{M}\left[{ }^{125} \mathrm{C}\right] \mathrm{GnRH}-\mathrm{II}$ and 0 or $10^{-10_{-}}-10^{-5} \mathrm{M}$ of the unlabelled competitor peptide (Hislop et al. 2000, 2001). Free and bound peptide were then separated by centrifugation through oil and radiolabel in the pellet was determined by $\gamma$-counting. For flat-plate binding assays approximately 50000 cells (grown in 24-well plates), were washed in PSS and then incubated in $200 \mu \mathrm{l}$ PSS containing approximately $10^{-10} \mathrm{M}\left[{ }^{125} \Pi \mathrm{GnRH}-\mathrm{II}\right.$ or approximately $10^{-10} \mathrm{M}$ $\left.{ }^{125}\right]$ Buserelin and either 0 (total binding) or $10^{-6} \mathrm{M}$ (non-specific binding) homologous competitor. The cells were rinsed in ice-cold PSS (three times) and solubilized in $0.5 \mathrm{ml} 0.2 \mathrm{M} \mathrm{NaOH}$ with $1 \%$ SDS. Radiolabel in the solubilized cells was determined by $\gamma$-counting. Receptor internalization was determined using a flat-plate binding assay in which cells were incubated for varied periods at $37^{\circ} \mathrm{C}$. The cells were rapidly rinsed twice in ice-cold PSS to terminate the incubation and then incubated for 2 min in either ice-cold PSS or ice-cold PSS with $50 \mathrm{mM}$ acetic acid $(\mathrm{pH} 3)$. The cells were then washed three more times in ice-cold PSS and solubilized in $0.5 \mathrm{ml}$ $0 \cdot 2 \mathrm{M} \mathrm{NaOH}$ with $1 \%$ SDS and this was collected for $\gamma$-counting. Specific cell-associated radioactivity was determined by subtraction of non-specific radioactivity from the total. Total specific binding is defined as the specific binding in cells receiving no acid wash, whereas acid-resistant (internalized) specific binding is defined as that seen in the acid-washed cells. An internalization index was calculated by expressing acid-resistant specific binding as a percentage of total cell-associated specific binding.

\section{$\mathrm{Ca}^{2+}$ imaging and accumulation of $\left[{ }^{3} \mathrm{H}\right] \mathrm{IP} \mathrm{x}_{\mathrm{x}}$}

The cytoplasmic $\mathrm{Ca}^{2+}$ concentration was measured by video imaging in fura 2-loaded cells as described by McArdle et al. (1992) and Everest et al. (2001). Briefly, cells were seeded onto glass coverslips at 50000 cells $/ \mathrm{ml}$ and transfected with cDNAs encoding wild-type or chimeric GnRHRs. After incubation for a further $24 \mathrm{~h}$ they were washed in PSS and then exposed to $2 \mu \mathrm{M}$ fura-2/acetoxymethyl ester (in PSS) for $30 \mathrm{~min}$ at $37^{\circ} \mathrm{C}$. The coverslips were then washed and loaded into a stainless steel holder fitted into a heating chamber at $37^{\circ} \mathrm{C}$. Image capture was performed within 5-25 min of loading in approximately $500 \mu \mathrm{l}$ PSS and calibration was as described previously (McArdle et al. 1992, 1995). $\left[{ }^{3} \mathrm{H}\right] \mathrm{IP}_{\mathrm{x}}$ accumulation was also used as a measure of PLC activity using cells labeled by pre-incubation with $\left[{ }^{3} \mathrm{H}\right]$ inositol and stimulated in the presence of $\mathrm{LiCl}$, as described by Hislop et al. (2000, 2001).

\section{Confocal microscopy}

Arrestin/GFP redistribution was assessed in HeLa cells as described previously (Mundell et al. 2000). Briefly, cells were seeded onto glass coverslips and transfected as described above with $2 \mu \mathrm{g}$ pCR3 containing the appropriate GnRHR vector, and $0 \cdot 1-0 \cdot 4 \mu \mathrm{g}$ arrestin/ GFP. The coverslips were then washed and loaded into a stainless steel holder fitted into a heated chamber at $37^{\circ} \mathrm{C}$. Image capture was performed within $5 \mathrm{~min}$ of loading in approximately $1 \mathrm{ml}$ Phenol Red-free Hepes-buffered DMEM containing 2\% serum. To assess arrestin/GFP distribution, cells were incubated for $10 \mathrm{~min}$ at $37^{\circ} \mathrm{C}$ following addition of $1 \times 10^{-6} \mathrm{M}$ GnRH-II or Buserelin, taking optical sections every $30 \mathrm{~s}$ using a Leica TCS-SP2 confocal laser-scanning microscope attached to a Leica DM IRBE inverted epifluorescence microscope with a $63 \times$ HCX Apo BL $1 \cdot 40$ numerical aperture oil-immersion objective. Excitation was performed using the $488 \mathrm{~nm}$ line of a $65 \mathrm{~mW}$ argon laser and images collected at $2 \times$ electronic zoom before processing with Leica LCSLite software. Alternatively, cells were prepared and transfected as above, stimulated for $30 \mathrm{~min}$ with 0 or $10^{-6} \mathrm{M}$ GnRH-II, washed in ice-cold PBS and fixed for $5 \mathrm{~min}$ in $4 \%$ paraformaldehyde. They were then washed three times for 5 min with PBS with agitation. They were then permeabilized as above and blocked for $3 \mathrm{~h}$ (PBS, $0 \cdot 1 \%$ Triton and $1 \%$ BSA), before being washed and incubated for a further $16 \mathrm{~h}$ at $4{ }^{\circ} \mathrm{C}$ with Alexa Fluor 594 conjugated anti-hemagglutinin (1:400). Cells were then washed a further three times before being mounted onto glass slides, imaged and processed as above.

\section{Statistical analysis and data presentation}

The figures show the means \pm S.E.M. from data pooled from $n$ independent experiments (raw data or data normalized as described in the figure legends) except for the $\mathrm{Ca}^{2+}$ imaging, where $n$ indicates the number of cells imaged, and the confocal microscopy, where the images 
shown are representative of those obtained in at least three separate experiments. Data are typically reported in the text as means \pm S.E.M. and statistical analysis was by analysis of variance (ANOVA) and Student's $t$-test (accepting $P<0.05$ as statistically significant).

\section{Results}

In the first experiments an acid-wash procedure was used to monitor receptor internalization in K44A HeLa cells infected with Ad expressing the human or Xenopus type I GnRHR and cultured with tetracycline (to suppress K44A dynamin expression) and, as shown (Fig. 2, upper panels), the XGnRHR was internalized faster than the hGnRHR (see also Hislop et al. 2000, 2001). Omission of tetracycline (to permit transgene expression and block dynamin function) slowed internalization of the XGnRHR but not that of the hGnRHR (Fig. 2, upper panels; see also Hislop et al. 2001). We suspected that dynamin-sensitive hGnRHR internalization might be revealed at higher transgene expression levels and therefore re-assessed internalization using recombinant Ad to express K44A dynamin 1. In these experiments infection with Ad expressing $\mathrm{K} 44 \mathrm{~A}$ dynamin at $3 \times 10^{6}$ p.f.u. $/ \mathrm{ml}$ caused nearmaximal inhibition of XGnRHR internalization (Fig. 2, middle panel) and a protein-expression level similar to that seen when K44A HeLa cells are deprived of tetracycline (Fig. 2, lower panel). Increasing Ad titre to $300 \times 10^{6}$ p.f.u. $/ \mathrm{ml}$ increased K44A dynamin expression by approximately 100 -fold but had little additional effect on XGnRHR internalization and Ad expressing K44A dynamin 1 failed to reduce hGnRHR internalization, even at the highest Ad titre.

To identify regions conferring dynamin-dependence we constructed three chimeric receptors (Fig. 1) consisting of the hGnRHR with substitution of the third intracellular loop for that of the XGnRHR (h.XlGnRHR), or addition of the XGnRHR G-terminal tail (h.XtGnRHR) or both (h.Xl.XtGnRHR). When cells were transfected with each of these constructs $(1 \mu \mathrm{g} / \mathrm{ml}$ pCR3; Superfect) radioligand binding revealed high levels of receptor expression (5-7.5 fmol/well) for each of the receptors containing the XGnRHR C-terminal tail. Binding was considerably lower with the hGnRHR (approximately $1 \mathrm{fmol} /$ well) and was so low with the h.XlGnRHR (approximately $0.2 \mathrm{fmol} /$ well) that meaningful assessment of ligand specificity was not possible (results not shown). In competition binding assays with the remaining four constructs (Fig. 3) all had high affinity (low-nanomolar $K_{\mathrm{d}}$ values) for their cognate ligands $\left(\left[{ }^{125} \Gamma\right] \mathrm{GnRH}-\mathrm{II}\right.$ for the XGnRHR and $\left[{ }^{125} I\right]$ Buserelin for the other receptors) and had the ligand specificity expected from the transmembrane and extracellular regions expressed $(\mathrm{GnRH}-\mathrm{II}>$ Buserelin at the XGnRHR and Buserelin $>$ GnRH-II at the other three). When receptor function was assessed by $\mathrm{Ca}^{2+}$ imaging (see trace insets in Fig. 3), the wild-type GnRHRs mediated the anticipated robust increase in $\left[\mathrm{Ca}^{2+}\right]_{\mathrm{i}}$ (see also Hislop et al. 2001, Willars et al. 2001) and a similar response was seen in cells transfected with the h.XtGnRHR construct. No such increase was seen in cells transfected with the h.XlGnRHR although this may simply reflect low expression of the receptor (results not shown). However, transfection with the vector encoding h.Xl.XtGnRHR led to high levels of expression and still failed to mediate an increase in $\left[\mathrm{Ca}^{2+}\right]_{\mathrm{i}}$, indicating a lack of coupling to $\mathrm{G}_{\mathrm{q} / 11}$.

When internalization rates were determined in transiently transfected HeLa cells the XGnRHR again was internalized faster than the hGnRHR (Fig. 4; see also Hislop et al. 2000, 2001) but addition of the XGnRHR G-terminal tail failed to accelerate internalization. Indeed, internalization of the h.XtGnRHR was even slower than that of the hGnRHR (Fig. 4). Low receptor expression prevented measurement of h.XlGnRHR internalization but addition of the XGnRHR third intracellular loop to the h.XtGnRHR chimera increased internalization by approximately 4-fold (compare internalization of h.XtGnRHR and h.Xl.XtGnRHR at 30 and $60 \mathrm{~min}$ ).

We next assessed the arrestin-dependence of receptor internalization by comparing rates in cells transfected with the functional arrestin 3/GFP with that in cells transfected with $\Delta$-arrestin(319-418), a dominant negative construct that inhibits effects of arrestins 1 and 2 . These conditions were intended to provide maximal or minimal arrestin-dependent internalization. As expected, hGnRHR-internalization rates did not differ between these groups, whereas internalization of the XGnRHR was faster with arrestin 3/GFP than with $\Delta$-arrestin(319-418). Internalization of both of the chimeric receptors (h.XtGnRHR and h.Xl.XtGnRHR) was also faster with arrestin $3 / \mathrm{GFP}$ than with $\Delta$-arrestin(319-418), implying that the G-terminal tail facilitates arrestin-dependent internalization but is clearly not the only structural determinant of the internalization rate (Fig. 5, upper panel). These receptors were also co-transfected with arrestin 3/GFP so that effects on distribution could be determined by confocal microscopy. As expected, the XGnRHR caused translocation of the fusion protein to the plasma membrane whereas the hGnRHR failed to do so (Fig. 5). The h.XtGnRHR also caused arrestin 3/GFP translocation (in spite of the fact that it is internalized slower than the hGnRHR) and the h.Xl.XtGnRHR caused similar translocation (in spite of the fact that it does not mediate $\mathrm{Ca}^{2+}$ mobilization). Similar data were obtained when arrestin 2/GFP was used in place of arrestin 3/GFP (e.g. the XGnRHR mediated clear translocation, whereas the hGnRHR failed to do so). 

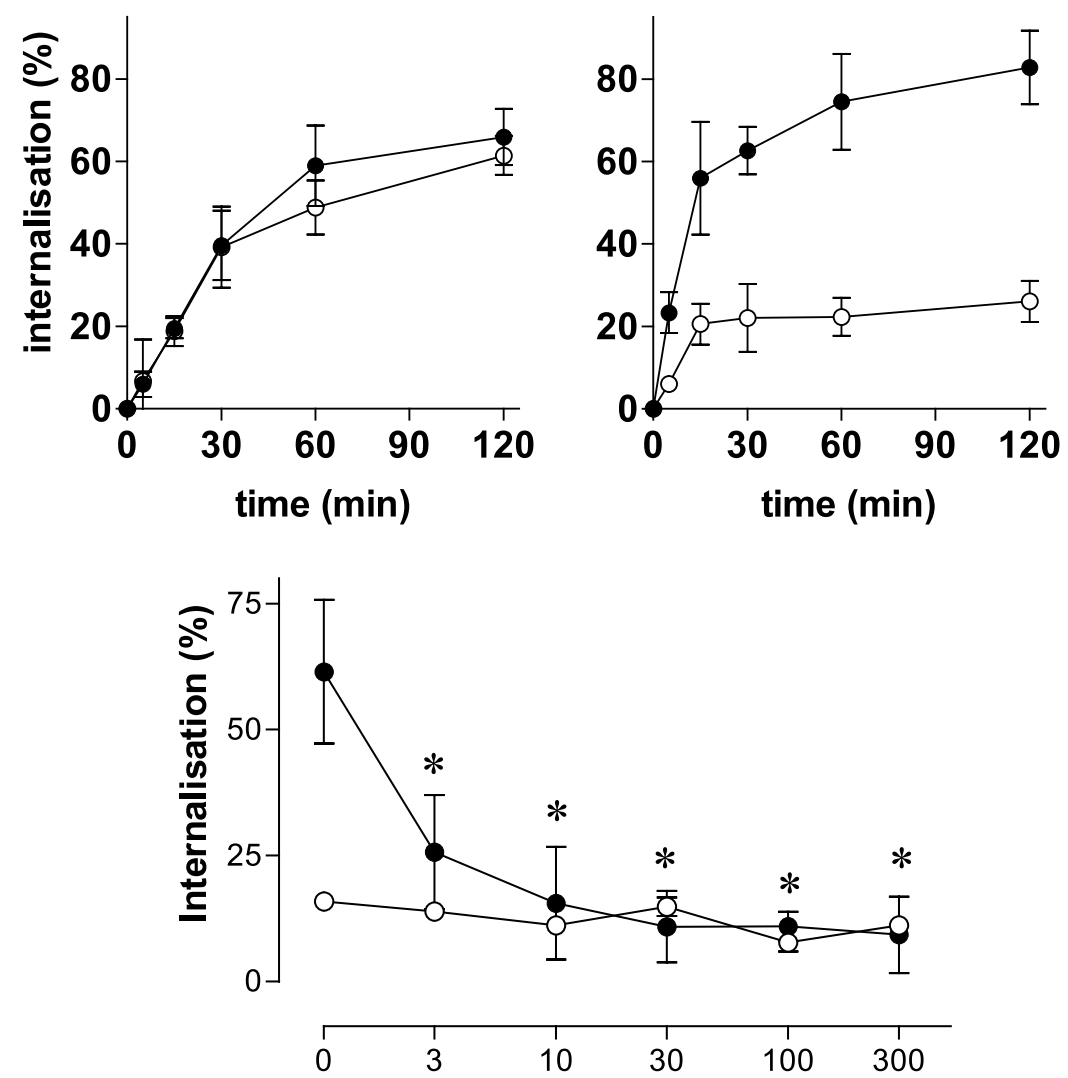

Ad K44A dynamin 1 (pfu/mlx10 ${ }^{6}$ )

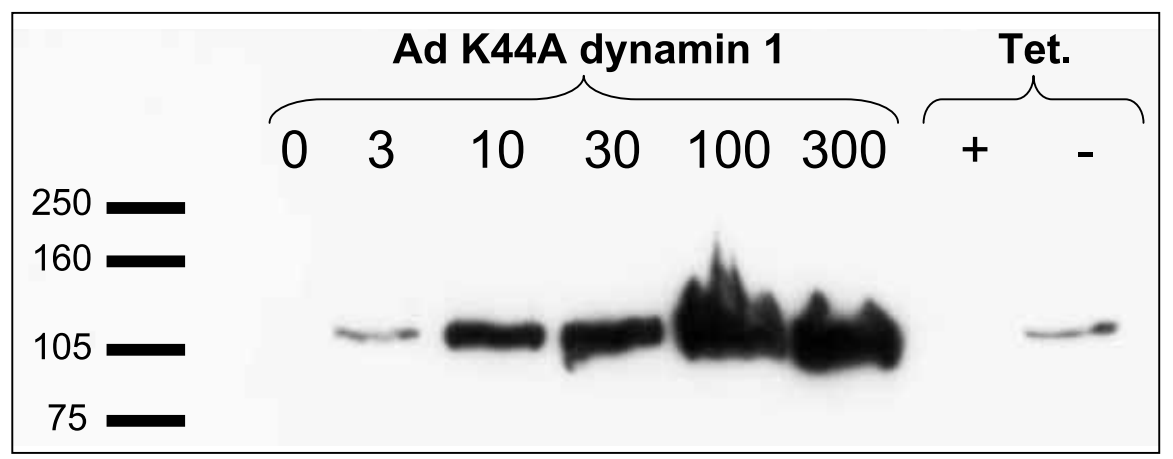

Figure 2 Influence of K44A dynamin 1 on GnRHR internalization. Upper panels: cells were infected with Ad hGnRHR (left) or Ad XGnRHR (right) and then incubated for $18 \mathrm{~h}$ in medium without tetracycline $(\bigcirc$; K44A dynamin expression permitted) or with $1 \mu \mathrm{g} / \mathrm{ml}$ tetracycline (๑; K44A dynamin expression prevented). Internalization was assessed using the acid-wash procedure with $\left[{ }^{125}\right]$ Buserelin (hGnRHR) or [125I]GnRH-II (XGnRHRs) and incubations were at $37^{\circ} \mathrm{C}$ for the periods shown. Specific acid-resistant binding is expressed as a percentage of specific total cell binding and used as a measure of receptor internalization. The values shown are means \pm S.E.M. $(n=3-5)$ pooled from five separate experiments (each with triplicate determinations). Expression of $\mathrm{K} 44 \mathrm{~A}$ dynamin 1 significantly reduced internalization of the XGnRHR $(P<0.05$ at all time points) but not that of the hGnRHR $(P>0.1$ at all time points). Middle panel: HeLa cells were infected with Ad hGnRHR (○) or Ad XGnRHR (๑), each at $10^{7}$ p.f.u./ml, and with Ad $\mathrm{K} 44 \mathrm{~A}$ dynamin at the indicated titre. They were then cultured for a further $18 \mathrm{~h}$ before use in an internalization assay. Data are means \pm S.E.M. $(n=3)$ pooled from three separate experiments (each with duplicate determinations) in which Ad K44A significantly reduced XGnRHR internalization at all titres $\left({ }^{\star} P<0.05\right)$ but did not measurably alter hGnRHR internalization at any titre $(P>0.1)$. Lower panel: Western blotting was performed to identify the hemagglutinin epitope on the K44A dynamin 1 . For the first six lanes (from the left) proteins were extracted from HeLa cells infected with Ad K44A dynamin 1 at the indicated titre (plaque forming units per $\left.\mathrm{ml} \times 10^{6}\right)$. For comparison, proteins were also extracted from K44A HeLa cells that had been cultured with (+) or without $(-)$ tetracycline (Tet) as described for the upper panels. Blots performed with an antibody directed against actin confirmed even loading of lanes (not shown). 

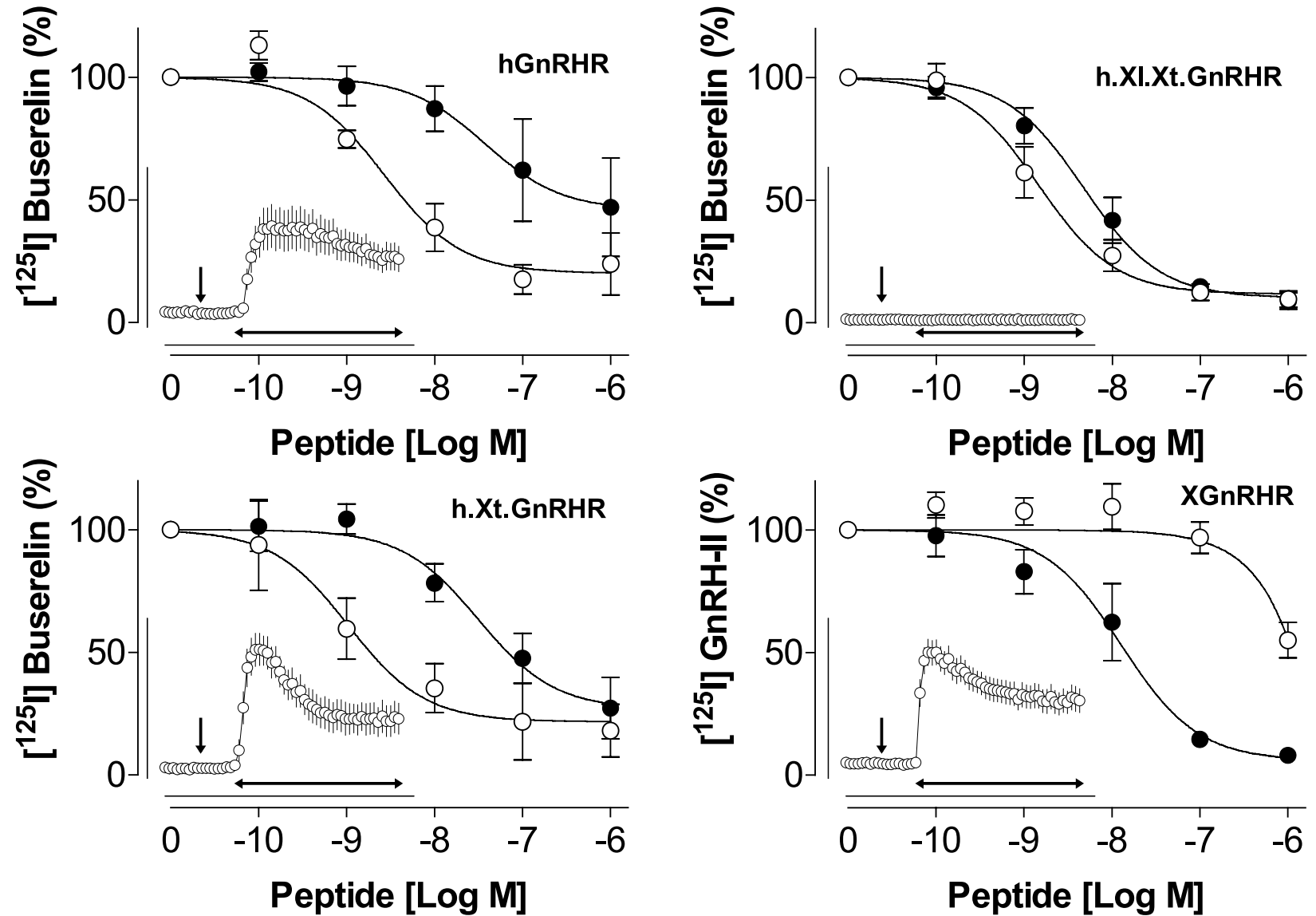

Figure 3 Competition binding and $\mathrm{Ca}^{2+}$ imaging with wild-type and chimeric GnRHRs. HeLa cells were transiently transfected with vectors encoding the indicated receptors and then used in flat-plate binding assays in which they were incubated for 30 min at $21^{\circ} \mathrm{C}$ with approximately $10^{-10} \mathrm{M}\left[{ }^{125} \mathrm{I}\right] \mathrm{GnRH}-\mathrm{II}(\mathrm{XGnRHR})$ or $\left[{ }^{125} \mathrm{I}\right]$ Buserelin (all other receptors) and the indicated concentration of unlabelled $\mathrm{GnRH}-\mathrm{II}(\mathbf{O})$ or Buserelin $(\bigcirc)$. The figure shows mean \pm S.E.M. $(n=3-4)$ values for specific binding from four experiments each expressed as a percentage of the control (without competitor). Insets: cells were transiently transfected with the indicated GnRHRs and used for $\mathrm{Ca}^{2+}$ imaging as described in the Materials and methods section. During imaging they received a control medium change (vertical arrow) and were then stimulated (horizontal arrows) with $10^{-7} \mathrm{M}$ agonist (GnRH-II for the XGnRHR; GnRH for the others). The insets show intracellular $\left[\mathrm{Ca}^{2+}\right]$ (vertical axes, 0-1000 nM) plotted against time (0-250 s). For the wild-type and h.XtGnRHRs, robust $\left[\mathrm{Ca}^{2+}\right]$ responses were seen in $10-40 \%$ of cells and the data shown are means \pm S.E.M. from 20-30 such responsive cells. Since no $\mathrm{Ca}^{2+}$ responses were seen for the XI.XtGnRHR these traces show data from comparable numbers of randomly selected cells.

In order to test for a possible role of Src or MEK, we measured internalization of the hGnRHR, the XGnRHR and the h.XtGnRHR chimera in the presence and absence of the Src inhibitor SU6656 and the MEK inhibitor PD98059 (Sorkina et al. 2002). As shown in Fig. 6 neither inhibitor had any measurable effect on internalization of any of these receptors. We next addressed the dynamin-dependence of internalization of the chimeric receptors. When K44A HeLa cells were infected with Ad h.XtGnRHR and cultured with $1 \mu \mathrm{g} / \mathrm{ml}$ tetracycline, the chimera was internalized slower than either of the wild-type receptors (Fig. 4). Expression of K44A dynamin further reduced the internalization of these receptors (Fig. 7, upper panel) although the effect was less pronounced than that seen with XGnRHRs in this model (e.g. at the 30-min time point tetracycline omission reduced h.XtGnRHR internalization by approximately $30 \%$ but reduced XGnRHR internalization by approximately $70 \%$; compare Figs 7 and 2). In a related series of experiments internalization of the h.Xl.XtGnRHR was assessed after transient transfection in HeLa cells and this was also found to be dynamin-dependent (Fig. 7, lower panel).

In a final series of experiments we assessed possible functional interactions between K44A dynamin 1 and $\Delta$-arrestin(319-418) or arrestin 3/GFP in regulation of XGnRHR internalization. As shown, XGnRHR internalization was reduced significantly by $\mathrm{K} 44 \mathrm{~A}$ dynamin 1 and by $\Delta$-arrestin(319-418) but the effect of both dominant negative proteins in combination did 


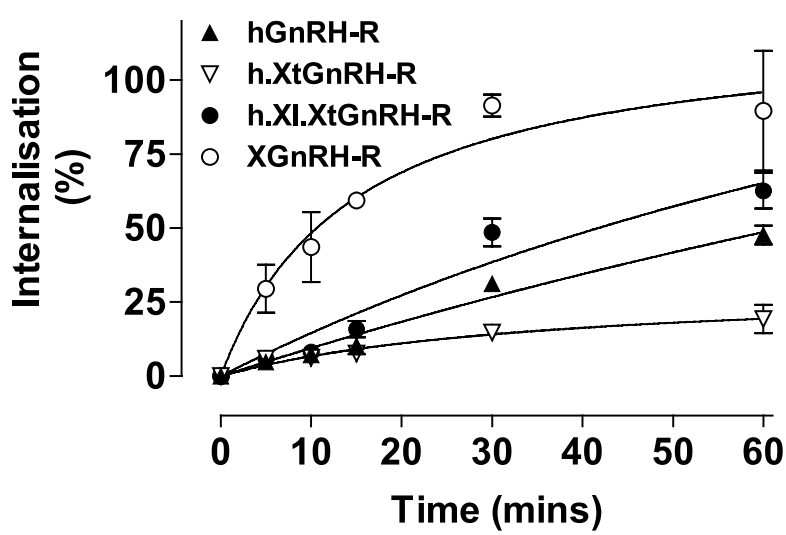

Figure 4 Internalization kinetics of wild-type and chimeric GnRHRs. HeLa cells were transfected with vectors encoding the indicated wild-type or chimeric GnRHRs. They were then used in internalization assays as described for Fig. 2. The figure shows mean \pm S.E.M. $(n=3)$ from three separate experiments.

not differ from that of either alone (Fig. 8, upper panel). In these experiments XGnRHR internalization was increased by arrestin 3/GFP and reduced by K44A dynamin (Fig. 8, middle and lower panels) and, interestingly, arrestin 3/GFP caused a clear increase in XGnRHR internalization even in K44A dynamintransfected cells (Fig. 8, lower panel).

\section{Discussion}

The known GnRHRs can be divided broadly into two structurally and functionally distinct groups. The non-mammalian GnRHRs and type II primate GnRHRs are selective for GnRH-II and possess C-terminal tails whereas the type I mammalian GnRHRs are selective for GnRH-I (also known as mammalian GnRH or simply as $\mathrm{GnRH}$ ) and lack-C-terminal tails. The latter mediate neuroendocrine control of reproduction in mammals and the unique lack of a $\mathrm{C}$-terminal tail in these receptors is thought to underlie their resistance to desensitization and their relatively slow rate of internalization. Where comparative studies have been performed, mammalian type I GnRHRs (e.g. human, sheep, mouse and rat) have been found not to undergo rapid homologous desensitization and to internalize only slowly, as compared with non-mammalian GnRHRs (e.g. catfish, chicken and Xenopus) that are desensitized and internalized rapidly (Davidson et al. 1994, McArdle et al. 1995, 1996, 2002, Heding et al. 1998, 2000, Vrecl et al. 1998, Willars et al. 1998, 2001, Blomenrohr et al. 1999, Hislop et al. 2000, 2001). Here we show (Fig. 5) that XGnRHR internalization is faster in HeLa cells co-expressing arrestin 3/GFP than in cells expressing the dominant negative $\Delta$-arrestin(319-418) and that
XGnRHR activation also causes translocation of arrestin/GFP to the plasma membrane (a marker for receptor phosphorylation and rapid homologous desensitization). On more sustained stimulation (15-45 min) arrestin/GFP redistributes to punctate regions within the cytoplasm (presumed endosomes). When hemagglutinin-tagged XGnRHRs are expressed in these cells they are predominantly at the cell surface and ligand stimulation caused their rapid internalization into vesicles (results not shown). Dual-label confocal microscopy reveals that these internalized XGnRHRs are often co-localized with transferrin receptors and/or arrestins (results not shown). Together these data suggest that XGnRHR (like many other 7TM receptors) undergo rapid agonist-induced and arrestin-dependent internalization into clathrin-coated vesicles, where they are co-localized with arrestin. This is in sharp contrast to the hGnRHR, which undergoes relatively slow and arrestin-independent internalization (Figs 2 and 5), does not cause arrestin translocation (Fig. 5) and is not seen co-localized with transferrin or arrestins in endosomes (results not shown).

As a further distinction between these receptors we have found that internalization of the XGnRHR is dynamin-dependent (e.g. inhibited by K44A dynamin 1), whereas internalization of the hGnRHR is not (Hislop et al. 2001). We initially suspected that this might reflect differences in receptor expression levels but excluded this by showing that receptor number does not influence the K44A dynamin-dependence of internalization of these receptors and that the distinction in dynamin-dependence of hGnRHR and XGnRHR internalization is seen at comparable receptor numbers (Hislop et al. 2001). Here we have considered the possibility that tetracycline-regulable expression in K44A HeLa cells might simply provide insufficient $\mathrm{K} 44 \mathrm{~A}$ dynamin 1 to reveal the dynamin sensitivity of hGnRHR internalization. However, this appears not to be so because infection with Ad expressing K44A dynamin does not inhibit hGnRHR internalization even at $3 \times 10^{8}$ p.f.u. $/ \mathrm{ml}$, a titre that is 100 -fold higher than that required for near-maximal inhibition of XGnRHR internalization and with which K44A dynamin expression is approximately 100-fold higher than that seen in tetracycline-deprived K44A HeLa cells (Fig. 2). Indeed, we see a similar distinction in the dynamin-sensitivity of internalization irrespective of whether the K44A dynamin is expressed by tetracycline deprivation of K44A HeLa cells, by infection with recombinant Ad or by transient transfection with cDNA (Figs 2, 7 and 8), and therefore used these strategies interchangeably.

Activation of GnRHRs has been shown to activate Src and ERK in a number of models and binding of the MAPK cascade proteins to arrestin 2 can mediate dynamin-dependent internalization of $\beta 2$-adrenergic receptor (Ahn et al. 1999, Luttrell 2003). Extending this 

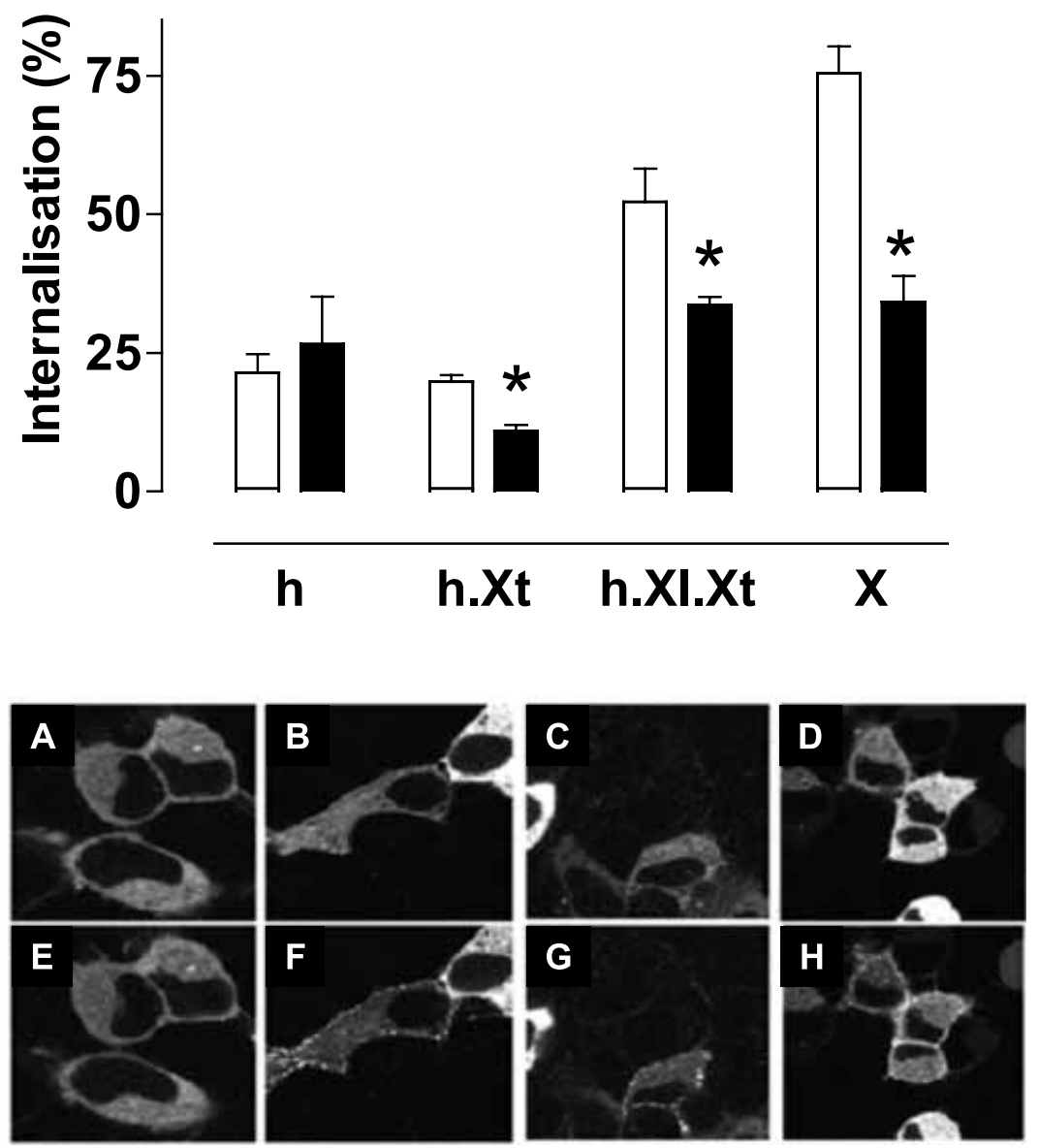

Figure 5 Arrestin-dependence of GnRHR internalization and agonist-induced translocation of arrestin/GFP. Upper panel: HeLa cells were transfected with the indicated wild-type or chimeric GnRHRs as well as with either arrestin 3/GFP or $\Delta$-arrestin(319-418). After a further $18 \mathrm{~h}$ in culture they were used in internalization assays as above. The figure shows mean+S.E.M. $(n=4-6)$ from experiments in which internalization rates were greater with arrestin 3/GFP than with $\Delta$-arrestin(319-418) for all receptors with the XGnRHR C-terminal tail ( $\left.{ }^{*} P<0.05\right)$ but not for the hGnRHR $(P>0.1)$. Lower panels: cells were cultured and transfected as described for Fig. 2 except that they were co-transfected with arrestin 3/GFP (all cells) and hGnRHR (A and E), h.XtGnRHR (B and F), h.XI.XtGnRHR (C and $G)$ or XGnRHR (D and H). Confocal microscopy was then used to monitor the cellular localization of arrestin 3/GFP before (A-D) and 5 min after $(\mathrm{E}-\mathrm{H})$ stimulation with $10^{-7} \mathrm{M} \mathrm{GnRH}-\mathrm{II}$ (XGnRHR) or GnRH (other receptors).

paradigm to GnRHRs, we hypothesized that arrestin binding to the C-terminal tails of non-mammalian GnRHRs might target them for dynamin- (and Src-) dependent internalization, in which case the differences in dynamin-dependence of internalization of human and Xenopus GnRHRs might actually reflect differences in their propensity for arrestin-mediated signaling. To test this we constructed a chimeric receptor by adding the C-terminal tail of the XGnRHR to the entire hGnRH. This receptor (h.XtGnRHR) is expressed at the cell surface and has similar binding (affinity and ligand specificity) and functional characteristics (mediation of
$\mathrm{Ca}^{2+}$ mobilization (Fig. 3) and $\left[{ }^{3} \mathrm{H}\right] \mathrm{IP}_{\mathrm{x}}$ accumulation (results not shown)) to the wild-type hGnRHR but, unlike the hGnRHR, it does mediate translocation of arrestin/GFP to the plasma membrane and then to vesicles (Fig. 5 and results not shown). Moreover, internalization of this receptor is both arrestindependent (Fig. 5) and dynamin-dependent (Fig. 7). We, and others, have found that wild-type and chimeric GnRHRs with C-terminal tails are typically expressed at higher levels than type I GnRHRs, presumably because the C-terminal tail increases stability of the expressed receptors (Lin et al. 1998) but, as with the wild-type 

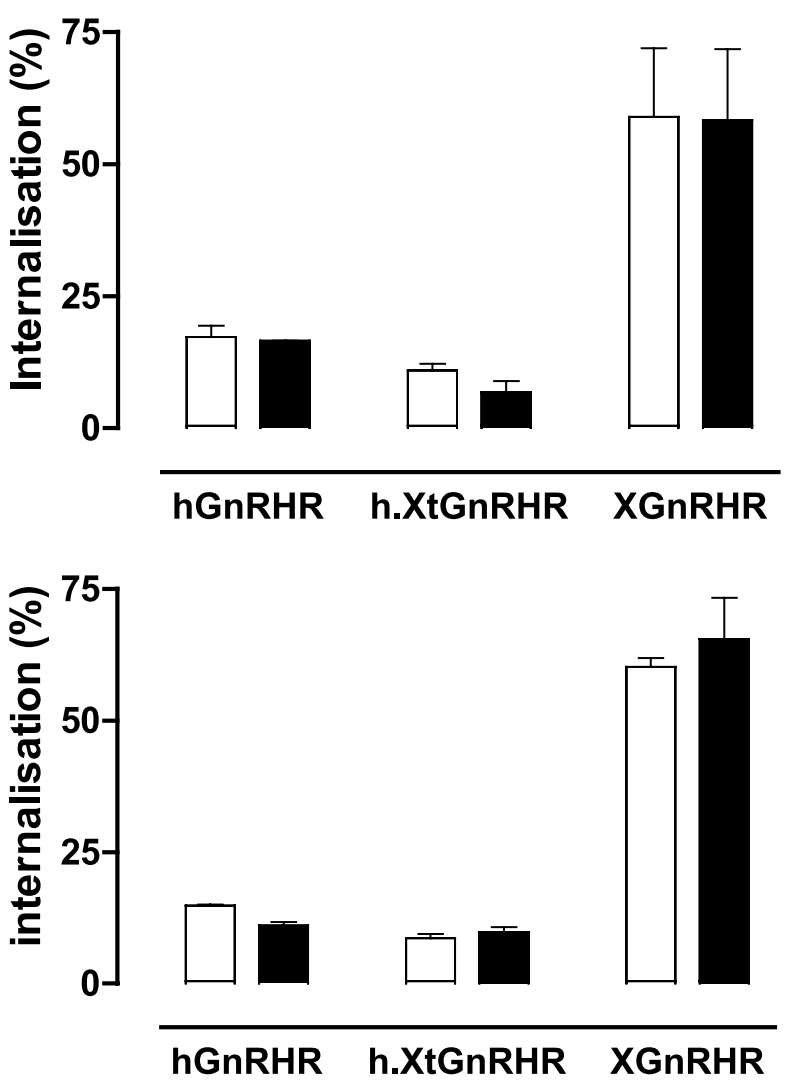

Figure 6 Src- and MEK-dependence of wild-type and chimeric GnRHR internalization. HeLa cells were transiently transfected with wild-type or chimeric GnRHR and then cultured before use in internalization assay, as described for Fig. 2, except that they were pre-treated for 60 min with (filled bars) or without (open bars) the Src inhibitor SU6656 (10 $\mu \mathrm{M}$; upper panel) or the MEK inhibitor PD98059 (20 $\mu \mathrm{M}$; lower panel) prior to the internalization assay. Both inhibitors were also retained in the medium during the 30-min internalization period. The data are means \pm S.E.M. from two or three separate experiments (each with duplicate observations) and internalization was not altered $(P>0.1)$ for any receptor by either inhibitor.

receptors, receptor number appears not to influence these aspects of receptor function (e.g. absolute rates and dynamin-dependence of h.XtGnRHR internalization were independent of receptor number when this was varied by varying Ad titre; results not shown).

Although addition of the XGnRHR tail to the hGnRHR targeted it for arrestin- and dynamindependent internalization, the h.XtGnRHR chimera was actually internalized slower than even the wild-type hGnRHR (Fig. 4). This was unexpected because sequential truncations of the chicken GnRHR slow internalization (Pawson et al. 1998) and addition of the thyrotropin-releasing hormone receptor C-terminal tail to the rat GnRHR accelerated internalization (Heding et al. 1998). Nevertheless, the slowed internalization of the h.XtGnRHR chimera clearly reveals that dynamin-
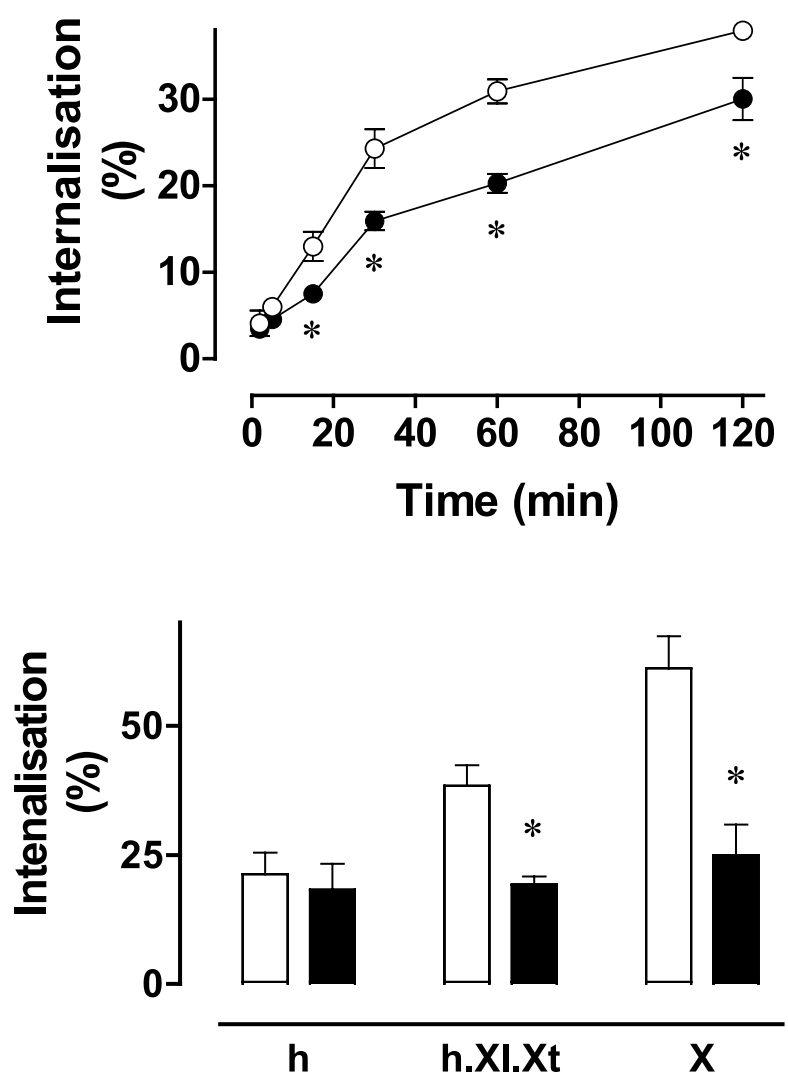

Figure 7 Dynamin-dependence of h.XtGnRHR and h.XI.XtGnRHR internalization. Upper panel: K44A HeLa cells maintained in culture medium with $1 \mu \mathrm{g} / \mathrm{ml}$ tetracycline were infected with Ad expressing the h.XtGnRHR chimera and then cultured for $18 \mathrm{~h}$ in medium with $1 \mu \mathrm{g} / \mathrm{ml}(\bigcirc)$ or no $(\bullet)$ tetracycline and then used in an internalization assay as described for Fig. 2. The figure shows mean \pm S.E.M. $(n=3)$ from three separate experiments in which tetracycline omission inhibited internalization as indicated $\left({ }^{*} P<0.05\right)$. Lower panel: HeLa cells were transiently transfected with vectors encoding the indicated wild-type or chimeric GnRHRs and incubated with Ad K44A dynamin as above. After a further $18 \mathrm{~h}$ in culture they were used in internalization assays as described for Fig. 2. The figure shows mean \pm S.E.M. $(n=3)$ from three separate experiments in which K44A dynamin 1 inhibited internalization of the h.XI.XtGnRHR and the XGnRHR $\left({ }^{*} P<0.05\right)$ but not that of the hGnRHR $(P>0 \cdot 1)$.

and arrestin-dependence are not necessarily indicative of rapid internalization, and implies that structures other than the C-terminal tail are required for such rapid internalization. Since sequences within the third intracellular loop have been implicated in internalization of other GPCRs, we constructed chimeras in which the third intracellular loop of the hGnRHR was exchanged with that from the XGnRHR but expression of this construct was too low for functional analysis. However, when the third intracellular loop exchange was combined with C-terminal tail addition (h.Xl.XtGnRHR) the dual chimera was expressed efficiently and 
had binding characteristics (affinity and specificity) comparable to the wild-type hGnRHR. The h.Xl.XtGnRHR mediated arrestin/GFP translocation to the plasma membrane and was internalized approximately four times faster than the h.XtGnRHR. Moreover, its internalization was dependent upon arrestin and dynamin (Figs 6 and 8). These data suggest that sequences in both the third intracellular loop and C-terminal tail underlie the rapid internalization of the
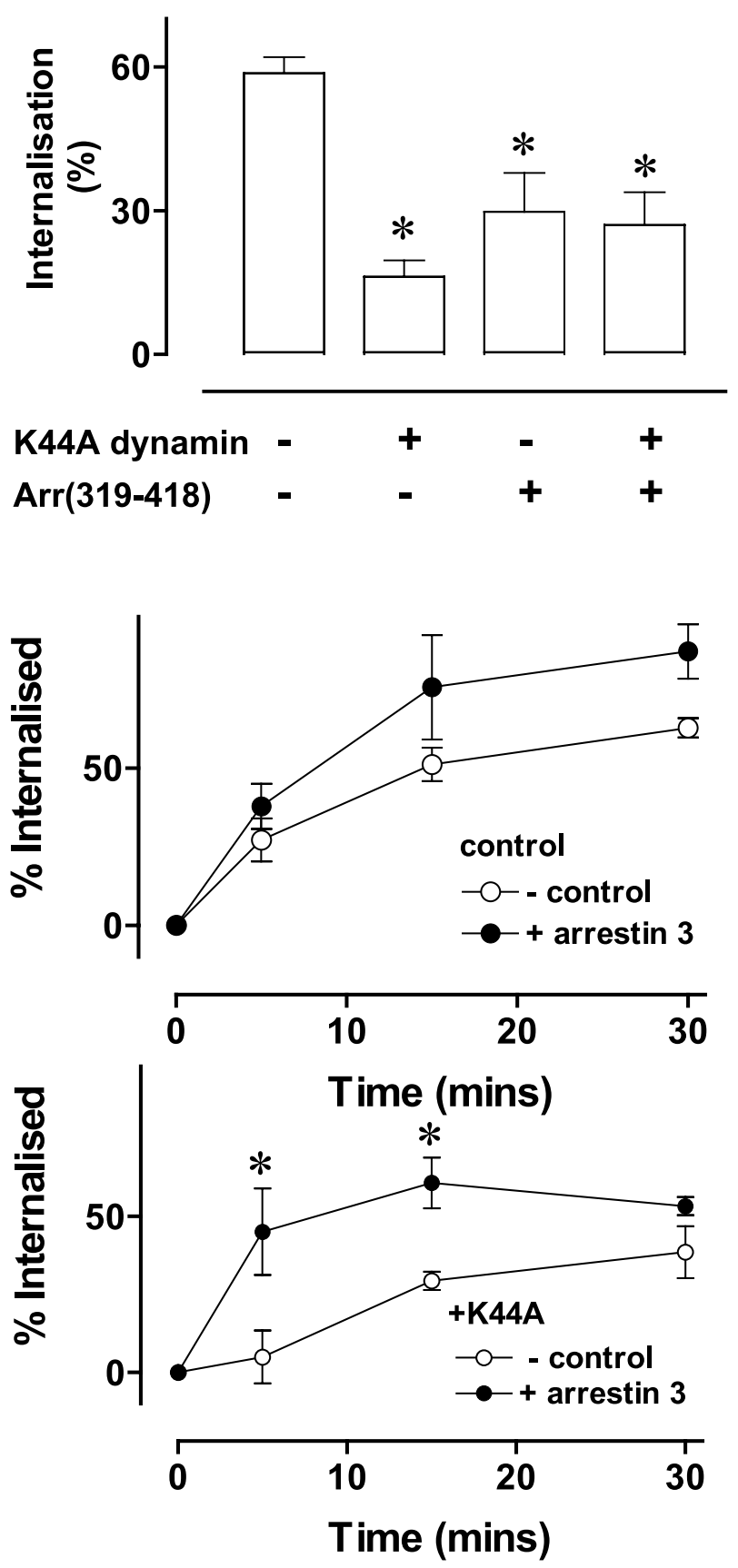

www.endocrinology-journals.org
$\mathrm{XGnRHR}$ and are again compatible with the possibility that arrestin-binding to the C-terminal tail targets the receptor for dynamin-dependent internalization. They were nevertheless unexpected because this dual chimeric receptor did not signal to $\mathrm{G}_{\mathrm{q} / 11}$ (as revealed by the lack of effect on cytoplasmic $\mathrm{Ca}^{2+}$ (Fig. 3) and $\left[{ }^{3} \mathrm{H}\right] \mathrm{IP}$ accumulation (results not shown)) and also had no measurable effect on $\mathrm{G}_{\mathrm{s}}$ or $\mathrm{G}_{\mathrm{i}}$ (as determined by measurement of cAMP accumulation (results not shown)). Thus it appears that G-protein activation is not necessary for rapid internalization via the arrestin- and dynamin-dependent route. This is somewhat surprising since G $\beta \gamma$ subunits are thought to activate GRK 2/3, kinases involved in desensitization and endocytosis of many 7TM receptors. This may also differ from the arrestin- and dynamin-insensitive route of hGnRHR internalization because introduction of an Ala-261 $\rightarrow$ Lys mutation that prevents PLC activation also slowed internalization of the hGnRHR in COS-1 cells (Myburgh et al. 1998). Moreover, the dynamin- and arrestin-dependence of internalization implies that ligand binding to the h.Xl.XtGnRHR stabilizes or induces a receptor conformation that does not activate G-protein but may nevertheless be recognized by GRK(s) and arrestin(s).

Our working hypothesis, that arrestins target G-terminal-tailed GnRHRs for Src- and dynamindependent internalization, predicts that effects of K44A dynamin 1 and $\Delta$-arrestin(319-418) would be comparable and not additive, and this proved to be the case for XGnRHRs (Fig. 8). However, it also predicts that the dynamin-dependent internalization of C-terminal-tailed GnRHRs will be Src-dependent and that arrestin will have no effect on XGnRHR internalization in K44A dynamin-transfected cells, both of which proved incorrect. Indeed, the Src inhibitor SU6656 and the

Figure 8 Dynamin and arrestin-dependence of XGnRHR internalization. Upper panel: HeLa cells were transfected with vectors encoding the XGnRHR (all cells) as well as the dominant negative $\Delta$-arrestin(319-418), as indicated. Where shown Ad K44A dynamin was added approximately $16 \mathrm{~h}$ later. Internalization was then assessed using the acid wash procedure as described for Fig. 2. The values shown are means \pm S.E.M. $(n=3)$ pooled from three separate experiments (each with triplicate determinations). Expression of K44A dynamin 1 and $\Delta$-arrestin(319-418) (alone or in combination) significantly reduced the internalization of the XGnRHR $\left({ }^{\star} P<0.01\right)$ but their effects alone did not differ from their effect in combination $(P>0 \cdot 1)$. Middle and lower panels: HeLa cells were transiently transfected with XGnRHRs and arrestin 3/GFP and transfected by infection with Ad K44A dynamin, then cultured and used for time-course internalization assays, as above. Note that the arrestin increased internalization in the presence of K44A dynamin $\left({ }^{*} P<0.05\right.$ at the 5 and 15 min points in lower panel) and that K44A dynamin did not alter internalization in arrestin 3/GFP transfected cells $(P>0.1$ at all time points; compare $\bullet$ middle and lower panels). 
MEK inhibitor PD98059 had no effect on internalization of the hGnRHR, XGnRHR or h.XtGnRHR (Fig. 6), and arrestin 3/GFP caused such a robust increase in internalization in the presence of $\mathrm{K} 44 \mathrm{~A}$ dynamin that the mutant actually failed to inhibit XGnRHR internalization in arrestin 3/GFP cotransfected cells (Fig. 8). This was particularly surprising because GnRHR internalization has been found to be either dependent upon both arrestin and dynamin (XGnRHR and chicken GnRHR), independent of both arrestins and dynamin (hGnRHR) or independent of arrestins but dependent upon dynamin (e.g. rat and marmoset type II GnRHRs (Heding et al. 2000, Pawson et al. 2003, Ronacher et al. 2004)), and because the effect of arrestin 2 on chicken GnRHR internalization was prevented by K44A dynamin 1 (Pawson et al. 2003). Thus, the arrestin-dependence of XGnRHR internalization in K44A dynamin-expressing cells (Fig. 8) reveals a novel functional route for GnRHR internalization. Moreover, this degree of plasticity in terms of internalization route was previously unrecognized for GnRHRs and implies that the route and/or mechanism by which the receptor is internalized may reflect not only receptor structure but also the amount of arrestin and dynamin expressed and active in any given cell type.

In summary, our data support earlier work implicating the C-terminal tail of non-mammalian GnRHRs in arrestin binding and provide strong evidence that such binding targets these receptors for dynamin-dependent internalization. However, this effect appears not to be mediated by Src or ERK scaffolded to arrestin and the G-terminal tail is not the only determinant of the internalization rate the third intracellular loop of the XGnRHR can also influence internalization). Moreover, the arrestin- and dynamin-dependent internalization route is not restricted to GnRHRs that adopt conformations causing $\mathrm{G}_{\mathrm{q} / 11}$ activation and arrestin can target a type I C-terminal-tailed GnRHR for dynaminindependent internalization.

\section{Acknowledgements}

This work was supported by a Wellcome Trust Project Grant award (to C A M). We are grateful to Professor R Millar (Medical Research Council Human Reproductive Sciences Unit, Edinburgh, UK), Professor J L Benovic (Thomas Jefferson University, Philadelphia, PA, USA), Professor S Schmidt (Scripps Institute, La Jolla, CA, USA) and Professor J Pessin (SUNY, New York, NY, USA) for providing materials. We also thank the MRC (UK) for an Infrastructure Award and Joint Research Equipment Initiative Grant to establish the Cell Imaging Facility at the University of Bristol, and Dr M Jepson and Dr A Leard for their assistance in its use. The authors declare that there is no conflict of interest that would prejudice the impartiality of this scientific work.

\section{References}

Ahn S, Maudsley S, Luttrell LM, Lefkowitz RJ \& Daaka Y 1999 Src-mediated tyrosine phosphorylation of dynamin is required for beta2-adrenergic receptor internalization and mitogen-activated protein kinase signaling. Fournal of Biological Chemistry 274 1185-1188.

Blomenrohr M, Heding A, Sellar R, Leurs R, Bogerd J, Eidne KA \& Willars GB 1999 Pivotal role for the cytoplasmic carboxyl-terminal tail of a nonmammalian gonadotropin-releasing hormone receptor in cell surface expression, ligand binding, and receptor phosphorylation and internalization. Molecular Pharmacology 56 1229-1237.

Caunt CJ, Hislop JN, Kelly E, Matharu AL, Green LD, Sedgley KR, Finch AR \& McArdle CA 2004 Regulation of gonadotropin-releasing hormone receptors by protein kinase $\mathrm{C}$ : inside out signalling and evidence for multiple active conformations. Endocrinology $1453594-3602$.

Conn PM \& Crowley Jr WF 1994 Gonadotropin-releasing hormone and its analogs. Annual Review of Medicine 45 391-405.

Davidson JS, Wakefield IK \& Millar RP 1994 Absence of rapid desensitization of the mouse gonadotropin-releasing hormone receptor. Biochemistry fournal 300 299-302.

Everest HM, Hislop JN, Harding T, Uney JB, Flynn A, Millar RP \& McArdle CA 2001 Signaling and antiproliferative effects mediated by $\mathrm{GnRH}$ receptors after expression in breast cancer cells using recombinant adenovirus. Endocrinology 142 4663-4672.

Finch AR, Green L, Hislop JN, Kelly E \& McArdle CA 2004 Signaling and antiproliferative effects of type I and II gonadotropin-releasing hormone receptors in breast cancer cells. Journal of Clinical Endocrinoogy and Metabolism 89 1823-1832.

Heding A, Vrecl M, Bogerd J, McGregor A, Sellar R, Taylor P L \& Eidne KA 1998 Gonadotropin-releasing hormone receptors with intracellular carboxyl-terminal tails undergo acute desensitization of total inositol phosphate production and exhibit accelerated internalization kinetics. Fournal of Biological Chemistry $\mathbf{2 7 3}$ 11472-11477.

Heding A, Vrecl M, Hanyaloglu AC, Sellar R, Taylor PL \& Eidne KA 2000 The rat gonadotropin-releasing hormone receptor internalizes via a beta-arrestin-independent, but dynamindependent, pathway: addition of a carboxyl-terminal tail confers beta-arrestin dependency. Endocrinology 141: 299-306.

Hislop JN, Madziva MT, Everest HM, Harding T, Uney JB, Willars GB, Millar RP, Troskie BE, Davidson JS \& McArdle CA 2000 Desensitization and internalization of human and Xenopus gonadotropin-releasing hormone receptors expressed in $\alpha \mathrm{T} 4$ pituitary cells using recombinant adenovirus. Endocrinology 141: $4564-4575$.

Hislop JN, Everest HM, Flynn A, Harding T, Uney JB, Troskie BE, Millar RP \& McArdle CA 2001 Differential internalization of mammalian and non-mammalian gonadotropin-releasing hormone receptors. Uncoupling of dynamin-dependent internalization from mitogen-activated protein kinase signaling. Fournal of Biological chemistry 276 39685-39694.

Horton RM, Hunt HD, Ho SN, Pullen JK \& Pease LR 1989 Engineering hybrid genes without the use of restriction enzymes: gene splicing by overlap extension. Gene 77 61-68.

Lin X, Janovick JA, Brothers S, Blomenrohr M, Bogerd J \& Conn PM 1998 Addition of catfish gonadotropin-releasing hormone $(\mathrm{GnRH})$ receptor intracellular carboxyl-terminal tail to rat $\mathrm{GnRH}$ receptor alters receptor expression and regulation. Molecular Endocrinology 12 161-171. 
Luttrell LM 2003 'Location, location, location': activation and targeting of MAP kinases by G-protein coupled receptors. Fournal of Molecular Endocrinology 30 117-126.

Luttrell LM \& Lefkowitz RJ 2002 The Role of beta-arrestins in the termination and transduction of G-protein-coupled receptor signals. Fournal of Cell Science 115 455-465.

McArdle CA, Bunting R \& Mason WT 1992 dynamic video imaging of cytosolic $\mathrm{Ca}^{2+}$ in the $\alpha \mathrm{T} 3-1$, gonadotrope-derived cell line. Molecular and Cellular Neuroscience 3 124-132.

McArdle CA, Forrest-Owen W, Willars G, Davidson J, Poch A \& Kratzmeier M 1995 Desensitization of gonadotropin-releasing hormone action in the gonadotrope-derived $\alpha \mathrm{T} 3-1$ cell line. Endocrinology $1364864-4871$.

McArdle CA, Willars GB, Fowkes RC, Nahorski SR, Davidson JS \& Forrest-Owen W 1996 Desensitization of gonadotropin-releasing hormone action in $\alpha \mathrm{T} 3-1$ cells due to uncoupling of inositol 1,4,5-trisphosphate generation and $\mathrm{Ca}^{2+}$ mobilization. Fournal of Biological Chemistry $27123711-23717$.

McArdle CA, Franklin J, Green L \& Hislop JN 2002 Signalling, cycling and desensitization of gonadotropin-releasing hormone receptors. Fournal of Endocrinology 173 1-11.

Millar RP 2002 GnRH II and type II GnRH receptors. Trends in Endocrinology and Metabolism 14 35-43.

Millar R, Lowe S, Conklin D, Pawson A, Maudsley S, Troskie B, Ott T, Millar M, Lincoln G, Sellar R et al. 2001 A novel mammalian receptor for the evolutionarily conserved type II GnRH. Proc Natl Acad Sci 98 9636-9641.

Miller WE \& Lefkowitz RJ 2001 Expanding roles for beta-arrestins as scaffolds and adapters in GPCR signaling and trafficking. Current Opinion in Cell Biology 13 139-145.

Morgan K, Conklin D, Pawson AJ, Sellar R, Ott TR \& Millar RP 2003 A transcriptionally active human type II gonadotropinreleasing hormone receptor gene homolog overlaps two genes in the antisense orientation on chromosome 1q.12. Endocrinology 144 423-436.

Mundell SJ, Matharu AL, Kelly E \& Benovic JL. 2000 Arrestin isoforms dictate differential kinetics of $\mathrm{A} 2 \mathrm{~B}$ adenosine receptor trafficking. Biochemistry 39 12828-12836.

Myburgh DB, Millar RP \& Hapgood JP 1998 Alanine-261 in intracellular loop III of the human gonadotropin-releasing hormone receptor is crucial for G-protein coupling and receptor internalization. Biochemistry fournal 331 893-896.

Neill JD, Duck LW, Sellers JC \& Musgrove LC 2001 A gonadotropin-releasing hormone $(\mathrm{GnRH})$ receptor specific for GnRH II in primates. Biochemistry and Biophysics Research Communication 282 1012-1018.

Pawson AJ, Katz A, Sun YM, Lopes J, Illing N, Millar RP \& Davidson JS 1998 Contrasting internalization kinetics of human and chicken gonadotropin-releasing hormone receptors mediated by C-terminal tail. Foumal of Endocrinology 156 R9-R12.
Pawson AJ, Maudsley SR, Lopes J, Katz AA, Sun YM, Davidson JS \& Millar RP 2003 Multiple determinants for rapid agonistinduced internalization of a nonmammalian gonadotropinreleasing hormone receptor: a putative palmitoylation site and threonine doublet within the carboxyl-terminal tail are critical. Endocrinology 144: 3860-3871.

Pierce KL, Premont RT \& Lefkowitz RJ 2002 Seven-transmembrane receptors. Nature Reviews in Molecular and Cell Biology 3: 639-650.

Ronacher K, Matsiliza N, Nkwanyana N, Pawson AJ, Adam T, Flanagan CA, Millar RP and Katz AA 2004 Serine residues 338 and 339 in the carboxyl-terminal tail of the type II gonadotropinreleasing hormone receptor are critical for beta-arrestinindependent internalization. Endocrinology 145: 4480-4488.

Sealfon SC, Weinstein H \& Millar RP 1997 Molecular mechanisms of ligand interaction with the gonadotropin-releasing hormone receptor. Endocrine Reviews 18 180-205.

Sorkina T, Huang F, Beguinot L \& Sorkin A 2002 Effect of tyrosine kinase inhibitors on clathrin-coated pit recruitment and internalization of epidermal growth factor receptor. Fournal of Biological Chemistry 277 27433-27441.

Stojilkovic SS \& Catt KJ 2000 Expression and signal transduction pathways of gonadotropin-releasing hormone receptors. Recent Progress in Hormone Research 50 161-205.

Vieira AV, Lamaze C \& Schmid SL 1996 Control of EGF receptor signaling by clathrin-mediated endocytosis. Science 274 2086-2089.

Vrecl M, Anderson L, Hanyaloglu A, McGregor AM, Groarke AD, Milligan G, Taylor OL \& Eidne KA 1998 Agonist-induced endocytosis and recycling of the gonadotropin-releasing hormone receptor: effect of $\beta$-arrestin on internalization kinetics. Molecular Endocrinology 12: 1818-1829.

Willars GB, McArdle CA \& Nahorski SR 1998 Acute desensitization of phospholipase C-coupled muscarinic M3 receptors but not gonadotropin-releasing hormone receptors co-expressed in alphaT3-1 cells: implications for mechanisms of rapid desensitization. Biochemistry fournal 333 301-308.

Willars GB, Heding A, Vrecl M, Sellar R, Blomenrohr M, Nahorski SR \& Eidne KA 1999 Lack of a C-terminal tail in the mammalian gonadotropin-releasing hormone receptor confers resistance to agonist-dependent phosphorylation and rapid desensitization. Fournal of Biological Chemistry 274 30146-30153.

Willars GB, Royall JE, Nahorski SR, El Gehani F, Everest H \& McArdle CA 2001 Rapid down-regulation of the type I inositol 1,4,5-trisphosphate receptor and desensitization of gonadotropinreleasing hormone-mediated $\mathrm{Ca}^{2+}$ responses in alpha T3-1 gonadotropes. Fournal of Biological Chemistry 276 3123-3129

Received 4 April 2005

Accepted 22 April 2005 